\title{
Local Magnates, but Mobile: Elite Dynamics in Byzantine Provinces
}

\section{"Local magnates" and "bureaucrats"}

The official elites of early Islamic Egypt are usually thought to have fundamentally differed - at least since the latter part of the seventh century - from the old local landowning aristocrats who had filled the ranks of the Byzantine provincial administration. ${ }^{1}$ Pagarchs - officials who were most notably responsible for the collection of taxes in the nomes of Byzantine and early Islamic Egypt - frequently serve as a prime illustration for this argument. ${ }^{2}$ In this conception, pagarchs were powerful local landowners who were largely independent from the Byzantine central authority, but became subject to a stricter hierarchy and more formal control after the Islamic conquest. Finally, it has been argued that the new government increasingly replaced these Christian magnates ${ }^{3}$ with a more bureaucratic Muslim elite who did not possess any landholdings in their areas of responsibility and whose tenures as pagarchs were part of their official cursus. In short: "their loyalty lay with their Arab Muslim colleagues, not with a local agricultural estate." ${ }^{4}$ A notable representative

1 This article was written under the auspices of the research project 162963: "Change and Continuities from a Christian to a Muslim Society - Egyptian Society and Economy in the 6th to 8th Centuries," funded by the Swiss National Science Foundation SNSF. I would like to thank my project colleagues as well as Jitse Dijkstra and Sven Tost for correcting the most apparent flaws in this paper, and Anthony Mahler for providing help with the English. I owe further thanks to Loreleï Vanderheyden, Sophie Kovarik, and Guus van Loon for sharing some of their work with me in advance. All remaining errors and shortcomings are, of course, my sole responsibility. If the exact date (month and day) is not essential for the argument, dates of papyri are only given by year.

2 On the pagarchs generally, see Mazza (1995) with further literature on p. 169 n. 1, and more recently Liebeschuetz (2001) 188-189, Banaji (2007) Chapters 4-6 passim, and Ruffini (2008) 187-195. The Egyptian nomes are generally viewed as having undergone a process of "municipalization" in the course of the Roman period, during which they legally became Roman cities (civitates or poleis) with their surrounding territories; see Maresch (2007) and Bagnall (1993) 54-62. In the early Islamic period, this administrative entity would have been called a pagarchia (e.g., in P.Lond. IV 1461.16, 22, etc.), which, in the Byzantine period, generally referred to the office of the pagarch and its official authority (e.g., in P.Oxy. XVI 1829.3). Throughout this paper, I shall employ the latter meaning for "pagarchy."

3 E. g., the pagarch Flavius Papas, who was a local landowner in the second half of the seventh century and whose father Flavius Liberios had already been a pagarch; see Foss (2009).

4 Sijpesteijn (2013) 210. I cite this work as the most recent comprehensive treatment of several aspects linked to this question; see also Papaconstantinou (2015). The more general argument of a more "efficient" government in the early Islamic period goes back to the earliest days of papyrology: prominent instances include Harold I. Bell in P.Lond. IV, p. xxiii, xxxv-xxxvii and Grohmann (1964) 
of these later pagarchs is 'Ațiyya b. Ju'ayd a.k.a. Flavius Atias, son of Goedos, who was pagarch of Arsinoe at least from 694 to 697 and was subsequently appointed dux of the province of Arcadia until 703 or 712 and at times even also covered the province of the Thebaid. Another example is Nājid b. Muslim, who was pagarch of Herakleopolis at least from 728 to 730 before being appointed pagarch of Arsinoe for some time between 730 and $750 .^{5}$

The evidence concerning pagarchs from early Islamic Egypt - particularly the archives of the pagarchs Flavius Papas (second half of the seventh century) and Flavius Basileios (early eighth century) - is admittedly replete with internal administrative letters that pagarchs received from their superiors, while hardly any such communications have survived from the Byzantine period. ${ }^{6}$ But this fact alone hardly proves that pagarchs were now more directly subordinate to their superiors. Here, the state of the evidence may be deceiving: the archives of Papas and Basileios comprise their own official papers, whereas the Byzantine pagarchs have left us nothing from their official bureaus. Instead, the Byzantine evidence on the pagarchs stems from other layers of administration - either from the village level, as in the case of the Dioscorus archive, or from the estates of landowners who happened to be pagarchs or wield pagarchic authority, as in the Oxyrhynchite and the Fayyūm.

This paper does not seek to call into doubt the elaborate integration of the pagarchs into the administration of the evolving Islamic empire, but to turn the question around: can the model elaborated from the more abundant early Islamic evidence on the pagarchs help us identify similar patterns in the sparser Byzantine material that would render the watershed supposedly marked by 'Ațiyya/Atias as perhaps less striking than it has often been taken to be? Naturally, within the context of the present volume, this article can only offer a preliminary treatment of this question, but rereading the relevant documents reveals various modes of integrating provincial elites - in patterns that seem remarkably close to those of the post-conquest period. To demonstrate this, I will tackle two aspects of the question posed above: what was the primary orientation of the ambitions and actions of these elites, and how mobile were they? Accordingly, this paper is organized around two wellknown nuclei of documentation for Byzantine Egypt: first, the Apiones archive

132-134. For a "Byzantine version" of this argument, stressing the importance of agricultural production to these large landholders, see Sarris (2006).

5 On 'Ațiyya, or Flavius Atias, see Sijpesteijn (2013) 201 n. 454, also pointing out that it is not certain whether 'Ativya was actually a Muslim; also Cromwell (2013) and Morelli (2014) $97 \mathrm{n}$. 2. See also Sijpesteijn (2013) $88 \mathrm{n}$. 286 on the lack of evidence for any landholdings in 'Ațiyya's possession. On Nājid, see Sijpesteijn (2013) 124-125 and passim. Cf., however, CPR XXIV 33, a receipt dating to 653 and addressed to an unknown individual who was possibly $d u x$ of Arcadia and pagarch of Arsi-

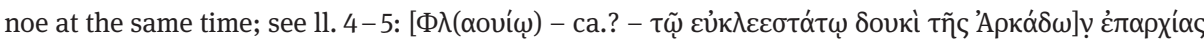

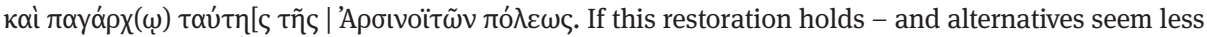

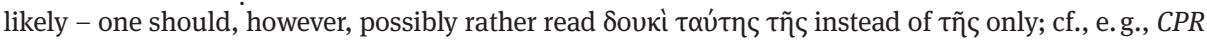
XIV 32.5-6 and P.Prag. I 64.6-7.

6 See Foss (2009) on the archive of Papas, and Richter (2010) on the archive of Basileios. 
and the papyri of the Fayyūm elites, and second, the archive of Dioscorus from the village of Aphrodito in the Antaiopolite nome. While the former presents us with pagarchs from the uppermost stratum of the Byzantine aristocracy, the latter yields far more instances of lower-ranking pagarchs. ${ }^{7}$

\section{Imperial and regional focus among Arcadian elites}

Of all the Byzantine Egyptian aristocrats, the Flavii Apiones of Oxyrhynchos have long served as prototypical examples of large landowners "infiltrating" the local administration and working toward personal (or dynastic) enrichment and local power at the expense of the state. ${ }^{8}$ But in recent decades, scholars have increasingly pointed to these elites' cooperation in matters of public concern, for instance, their assumption of official responsibilities through their oikoi (i.e., institutionalized "houses”). ${ }^{9}$ Furthermore, their horizon was clearly broader than their landholdings - and continuously focused toward the imperial center. The Apiones were most probably from Egypt, but they took up residence in Constantinople when they rose to high imperial honors during the course of the fifth century. ${ }^{10}$ Flavius Apion II, for instance, was granted the extraordinary honor of consul ordinarius in 539 - at a point when he was between a mere 10 and 21 years of age. ${ }^{11}$ He regularly bore the most-distinguished epithets hyperphyestatos and paneuphemos and later was even granted the title of patricius, which made him part of the top social stratum of the empire. ${ }^{12}$ In the Oxyrhynchite papyri, Apion II figures as a geouchōn in control of a local estate as early as 543, but these texts regularly feature an institutionalized formula of representation suggesting his absence. ${ }^{13}$ Nothing, in fact, indicates that Apion ever discharged

7 There is a wide spectrum of ranks among the pagarchs (see Gascou [1972] 69), and one finds most of the higher-ranking epithets attached to them: lamprotatos (Lat. clarissimus), peribleptos (Lat. spectabilis), megaloprepestatos (Lat. magnificentissimus), endoxotatos (Lat. gloriosissimus), hyperphyestatos (Lat. excellentissimus), paneuphemos (Lat. famosissimus). This is not the place to engage more deeply with the Byzantine aristocratic hierarchy; on that topic, still see Koch (1903) and Hornickel (1930), both in need of major revision.

8 E.g., Gelzer (1909) and Hardy (1931).

9 This interpretation has most prominently been advanced by Rémondon (1974) and Gascou (1985); see Hickey (2012) for the most recent elaborate defense of this model, particularly in response to Sarris (2006).

10 On the Apiones (and their "numbering”), see recently Hickey (2012) 8-18 and Mazza (2013) with further literature.

11 E.g., P.Oxy. I 133.4 (Oxyrhynchos; 550).

12 PSI III 191.1-2 (Oxyrhynchos; 565).

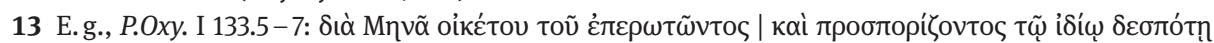

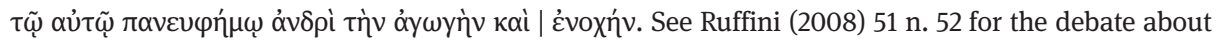
the significance of this formula. Its use as a "legal fiction" in cases of absence is advanced by Sarris (2006) 161 with n. 44. Other oiketai than Menas appear in connection with the Oxyrhynchite Apiones in P.Oxy. LXIII 4390.4-5 (Oxyrhynchos; 469), P.Oxy. LXXXII 5332.4-6 (Oxyrhynchos; 480), and P.Oxy. 
any office in Egypt. His pagarchic authority, then, is only indirectly attested: it is not part of his titulature, but it was added later in three documents concerning individuals hailing from a village that was "pagarchically administered" (pagarchoumenē) by Apion or by his "glorious house," the endoxos oikos. ${ }^{14}$ This illustrates that Apion was not a pagarch, but that his oikos had to bear a village-based "pagarchic responsibility" even in his absence. ${ }^{15}$ His father Strategios II and the later Apion III follow this pattern closely, and it is therefore probably misleading to conceive of the Apiones as pagarchs focused on their local powerbase. Quite the opposite was the case: the "pagarchic responsibility" served as a means to make these imperial magnates responsible for the imperial cause at the local level. ${ }^{16}$

Another prominent figure in Byzantine Egypt was Flavius Strategios Paneuphemos, who was pagarch of the Fayyūm and who, like Apion II, regularly bore the distinguished epithets hyperphyestatos and paneuphemos. ${ }^{17}$ Strategios also rose to the rank of patricius. In contrast to Apion II, however, Strategios is indeed personally addressed as pagarch in many legal documents dating from between 600 and 612, and their distribution suggests that he held the pagarchy continuously throughout this period, and possibly also earlier or later. ${ }^{18}$ As he is never represented in legal docu-

LXXXII 5337.5-6 (Oxyrhynchos; 493). Notable uses of this formula from other nomes include CPR XXIV 25.7-9 (Herakleopolis; 598), which concerns a Strategios (probably Strategios Paneuphemos, who will be discussed below) and his meizoteros, and P.Stras. IV 229.4-6 (Panopolites; 502), which concerns a singularis of the $d u x$ and his slave (pais).

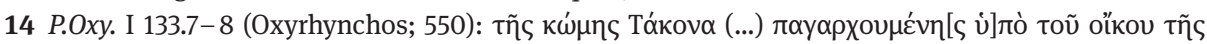

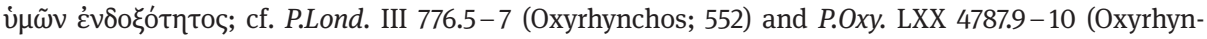

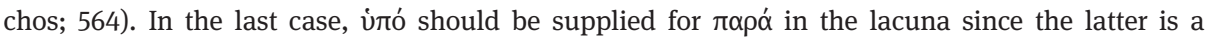
later variant.

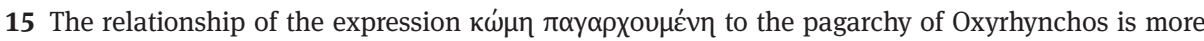
complicated than outlined here, but this is not the place to delve further into this issue. For our purposes, it is sufficient to equate both institutions, given their potential to tie elites to local administrative responsibilities; see Stern (2015) 142-143.

16 See also the regulations of Justinian's Edict XIII (539), which made the pagarchs (of Aegyptus and the Thebaid; the passages for Augustamnica and Arcadia are lost) subordinate to the duces et Augustales while the emperor retained the final verdict over their tenure - and, for that matter, over their ousiai (Chapters 12 and 25). This attests not only to the significance of the pagarchs' official responsibilities but also to their links to the central government.

17 On this man, see Palme (2016) 216-217 with further literature. Scholarship has added Strategios' most-reputable epithet to his name in order to distinguish him from the numerous other Byzantine Egyptian aristocrats called "Strategios," not least in the Apion family. The links of Strategios Paneuphemos (and those of another Apion, who was pagarch, stratēlatēs, and honorary consul) to the Oxyrhynchite Apiones, once unquestioned, have come under scrutiny in recent decades (see P.Oxy. LXX, p. 93) and are still far from clear.

18 E. g., SB XXIV 16288.5-6 (Arsinoe; 600). According to P.Cair.Masp. III 67002.10-11 (see also P.Cair.Masp. I 67283.2-3), the tenure of the Antaiopolite pagarch Menas, who will be discussed below, started with the inception of the indiction year. Counting in indiction years, Strategios is attested as pagarch in the years 3, 4, 9, 11, 13, and 15 of the indiction cycle of 597/598-612/613, leaving little, if any, room for a break in his tenure. 
ments the way the Apiones are, he appears to have been based in Egypt and to have formally conducted his public and private business himself. Strategios would clearly serve as one of Emperor Heraclius' right-hand men in Egypt - a role that even a passage in the chronicle of Michael the Syrian attests to. There, Strategios is involved, by imperial directive, in mediating at a meeting between the Alexandrian and Antiochean churches at Alexandria in $617 .^{19}$

A more pointed local focus was adopted by Flavius Menas, the endoxotatos stratēlatēs who succeeded Strategios Paneuphemos as pagarch. ${ }^{20}$ His landholdings are attested exclusively from the Fayyūm and his pagarchy there extended at least from 616 to 622. This means that his tenure witnessed the Persian occupation of Egypt from 619 to 629, which is particularly interesting since Menas, as endoxotatos stratēlatēs, was in a position occupied by very few people in Egypt at this time. ${ }^{21}$ It is remarkable to find someone as high in rank still in office after the Persian conquest, and it suggests that Menas found it worthwhile to save his regional standing rather than to flee. It has been proposed that this would have had serious consequences for him once Egypt fell back to the Byzantine empire in $629 .{ }^{22}$ But two documents most probably dating from after the reconquest still reference Menas' estate as an administrative unit under his name, and Menas is still granted the exceptional dignity of stratēlatēs, so his reputation cannot have taken much damage. ${ }^{23}$ But why was Menas not punished after 629 if he had collaborated with the Persian invaders? This case may illustrate, on the one hand, that Menas contented himself with a

19 See Van Loon (2017) 128-129 with further discussion and also Gascou (1985) 71 with n. 391. The date of this meeting, on which see Allen (2013) 197-198, is especially interesting because a new papyrus, published in Van Loon's article, shows Menas, the endoxotatos stratēlatēs - who will also be discussed below - as pagarch of the Fayyūm as early as 20 February 616. Since the new text has Strategios still alive, it is very likely that the latter was no longer pagarch at that time, and I would suppose that it is not a coincidence that Strategios acted as the emperor's delegate after he had laid down (or was deprived of) his pagarchy, which would underscore his personal involvement in regional official business. Though not impossible, it so far seems unlikely that Menas and Strategios were in office at the same time: the available spans (if they acted continuously during these periods, as is highly likely) for Strategios' and Menas' tenures are so clearly spread (600-612 vs. 616-622, adopting the closest possible dates for the relevant documents) that it would seem daring to assume that their tenures overlapped even for a short period. Moreover, the example of the Antaiopolite pagarchs Ioannes and Serenos appears to suggest that pagarchs in general jointly took office and also jointly stepped down; see Fournet (2000) 247.

20 On Menas, see Van Loon (2017) 128 with further literature.

21 See $C P R$ XXIV, p. 178.

22 CPR XXIV, p. 180.

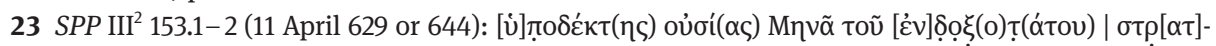

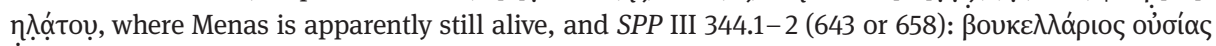

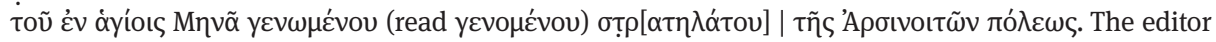
of $S P P$ III $^{2} 72$ A identifies the late endoxotatos stratēlatēs in this text, whose name is lost, with Menas, but as Sophie Kovarik has informed me, this text is far more likely to be from the end of the seventh century and the endoxotatos stratēlatēs may well be the Stephanos from P.Ross.Georg. III 53. 
strong position in the province, but it also suggests that such conduct was of minor significance for the central administration. For the role of the pagarchy was precisely a local one, and this apparently easy transition to a new regime indicates the pagarchs' firm place within the apparatus of local public administration. ${ }^{24}$

\section{Mobile bureaucrats in the Thebaid}

The Dioscorus archive features a strikingly different sort of pagarch, and the most famous of them is probably another Menas (the name was common), who may serve to exemplify a more mobile kind of bureaucrat. ${ }^{25}$ In 553, this Flavius Menas, a lamprotatos scriniarius, was pagarch of Antaiopolis as part of a collegium, although he was apparently not pagarch in his own right, but rather acting as a deputy for the endoxotatē Patrikia. ${ }^{26}$ He then held the pagarchy a second time starting from the beginning of the year 566/567 when he was still lamprotatos scriniarius, though there is no longer any reference to Patrikia. ${ }^{27}$ It is during this second tenure that the petitions of the poet-notary Dioscorus made Menas a notorious example of a class of large landowners aggressively repressing the late Roman peasantry. ${ }^{28}$ The last document to mention Menas dates to March 570 and does not attribute a pagarchy to him. ${ }^{29}$ Instead, this papyrus refers to him as "lamprotatos and peribleptos lord Menas, scriniarius of the noble ducal bureau of the Lower Thebaid." ${ }^{30}$ The epithet peribleptos is notable

24 See also the example of Flavius Theodorakios, who was pagarch of Arsinoe before and after the Islamic conquest, his tenure being so far narrowed down by W.Chr. 8 (639/640) and CPR XXIV 32 (4 May 651).

25 See Keenan (2001) 66-68 and 70; for a similar pattern in the province of Arcadia, see p. 72-73. On Menas, see Ruffini (2011) s.n. Menas 13. His local connections within the village of Aphrodito are analyzed by Ruffini (2008) 191-194. See also Loreleï Vanderheyden's contribution to the present volume: Menas makes some appearances in Dioscorus' unpublished Coptic letters.

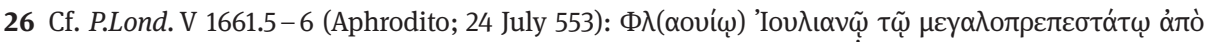

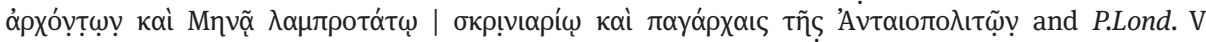

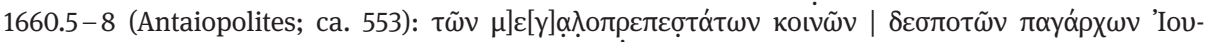

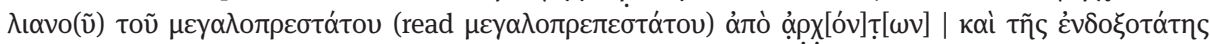


see below.

27 P.Cair.Masp. I 67002 col. I 6 and 9-11 (Antinoopolis; May-July 567). In view of the small overall number of texts, Patrikia's “absence” does not, however, necessarily have to mean anything.

28 See, e.g., Gelzer (1909) esp. 92-96, Bell (1917) 99-100, Hardy (1931) 137-138, and MacCoull (1988) passim. The episode features in P.Cair.Masp. I 67002, P.Aphrod.Lit. IV 3, P.Cair.Masp. I 67021, P.Lond. V 1674, and P.Lond. V 1677.

29 P.Lond.V 1714 (Antinoopolis; 14 March 570). Menas is only mentioned in a patronymic reference, which is generally not expected to provide his full titulature. The apparently active association with the ducal bureau certainly precluded him, however, from actively exercising the pagarchy in Antaiopolis.

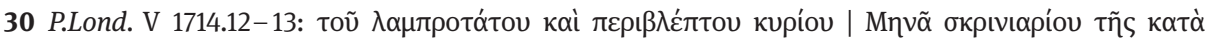

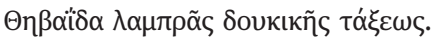


here, as it indicates a rank higher than that of a simple lamprotatos, and the fact that Menas now works for the provincial government in Antinoopolis indicates that Dioscorus' petitions cannot have got him into too much trouble. ${ }^{31}$ The same text attests to Menas' son Flavius Theodoros, "the lamprotatos exceptor of the same ducal bureau, hailing from Antaiopolis, where he is also a landlord (geouchōn)." ${ }^{32}$ It is highly uncommon for lamprotatoi to be referred to by their origin, and in this case the reason is probably that Theodoros was not from the city where he held his post: Theodoros hailed from Antaiopolis, where his father Menas had been pagarch. In this light, Menas emerges as a career bureaucrat who drew on his education as a scriniarius in order to attain a position otherwise out of his reach - the Antaiopolite pagarchy. By exercising this post, he recommended himself for higher positions and apparently also paved the way for his son's career.

As is apparent from the aforementioned text, many connections linked Antinoopolis, the capital of the Thebaid, with Antaiopolis, revealing a mobile elite with supralocal interests. In addition to the example of Menas, this is also illustrated by the pagarch Kollouthos. ${ }^{33}$ In one of his poems, Dioscorus hails Kollouthos as comes and pagarch, as an Antinoopolite councilor, and as a "leader of cities" who "saved" Antinoopolis, where Dioscorus was dwelling at that time. ${ }^{34}$ He goes on to identify Kollouthos as the brother of Kallinikos and Dorotheos, whom we know as high-ranking staff in the ducal bureau of the Thebaid under the dux Athanasios. Kollouthos' father, Apa Dios, is hailed as a "protector of cities" and, like his son, as a "leader of cities" who "saved" Antinoopolis. ${ }^{35}$ Certainly this family would have been based in the provincial capital. But in the same poem, Dioscorus also hails Kollouthos as an "eagle of the whole land of Aphrodito" who has "come to us to take pity on the whole land of Aphrodito, which suffers from lamentable troubles at the hands of your unjust predecessors." ${ }^{36}$ If this relates to the villagers' conflicts with the pagarch Menas, then the text may indicate that Kollouthos was pagarch

31 For "rehabilitations" of Menas, see Rémondon (1961) 86 and Geraci (1979). For a reading of this episode with regard to Menas' role in imperial policy, see Stern (forthcoming).

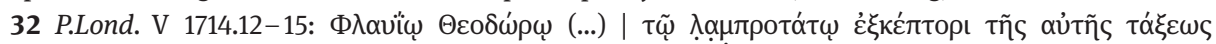

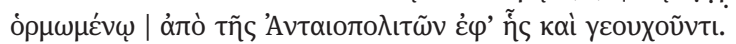

33 Ruffini (2011) s.n. Kollouthos 36.

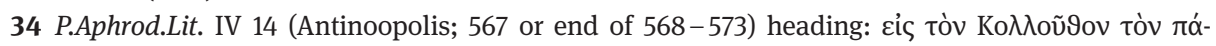

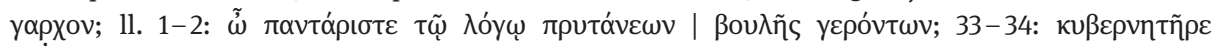


$547 / 550$ ?) also refers to him but does not contain any further information on his status. In the following, I have adapted the English translations found in MacCoull (1988) 96-97 and 100-101 according to Jean-Luc Fournet's reedition in P.Aphrod.Lit.

35 P.Aphrod.Lit. IV 14.33-34 and 44-45; Ruffini (2011) s.n. Kallinikos 17, Dorotheos 12, and Apa Dios 1.

36 P.Aphrod.Lit. IV 14.25 and 35-36. Dioskoros employs poetic aliases for the village of Aphrodito in both instances. 
of Antaiopolis, and, even more precisely, that he was Menas' successor. ${ }^{37}$ And indeed, in a petition to the $d u x$, a woman from Aphrodito writes that "my master, the lamprotatos lord Kollouthos, the cancellarius and pagarch, ordered that I be released [from prison]." 38 Since Aphrodito was situated in the Antaiopolite nome, the authority displayed here certainly implies that Kollouthos was pagarch of Antaiopolis, although we have no evidence that Kollouthos owned estates in the village of Aphrodito or anywhere else in the Antaiopolite. ${ }^{39}$ In any case, he apparently moved up the Nile to personally exercise the pagarchy there. An alternative explanation could be that Kollouthos was or had been pagarch not of Antaiopolis but of Antinoopolis and that he came to Aphrodito in another capacity (which "predecessors" would then only vaguely relate to), possibly as a delegate of the $d u x .^{40}$

In contrast to Menas, the scriniarius, the pagarch Flavius Ioulianos shares the rather high-ranking background of the three aforementioned members of the Arcadian elite. ${ }^{41} \mathrm{He}$ is a megaloprepestatos and endoxotatos pagarch, and he is additionally honored as a former praeses and illoustrios. ${ }^{42}$ He thus found himself at the upper end of the Thebaid aristocracy, owned estates in the Antaiopolite, and appears to have been personally involved in the performance of the Antaiopolite pagarchy in the

37 For this hypothesis, see also Harold I. Bell in P.Lond. V, p. 147.

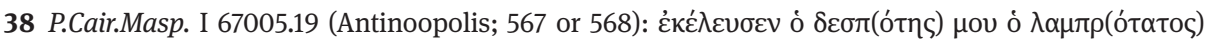

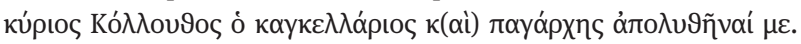

39 A possible match could be Ruffini's Kollouthos 8 (Ruffini [2011] s.n.), who was a landowner, but this man could equally well be Kollouthos 27, a scriniarius and landholder in Aphrodito whose filiation renders an identification with the pagarch Kollouthos of P.Aphrod.Lit. IV 14 impossible.

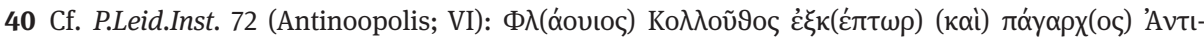
(vóou), but the name is common. See Fournet (1993) 234 n. 42 on the link and other possible but inconclusive identifications with various Thebaid provincial bureaucrats named Kollouthos. Also Mazza (1995) 204-205 with n. 110 refers to this discussion and hesitates to identify both Kollouthoi. Gelzer (1913) 361 and Liebeschuetz (1974) 163 n. 10 both assumed that Kollouthos was pagarch of Antaiopolis, but that was still before P.Leid.Inst. 72 had been published. Ruffini (2011) s.n. Kollouthos 36 does not consider this text. For the possibility that Kollouthos came to Aphrodito in a different capacity than that of a pagarch, see P.Aphrod.Lit. IV 14.32: $\kappa \nu \beta \varepsilon \rho v \eta \tau \tilde{\eta} \rho \varepsilon \pi$ r $\lambda \hat{\omega} \omega \nu$, "leader of cities," which Dioscorus elsewhere employs to refer to the $d u x$ (see the commentary). There is no evidence of a Byzantine pagarch holding pagarchies in two different nomes (the case of Arsinoe and Theodosiopolis is an exception due to the latter's territory being carved out of the Arsinoite nome), so this should not be the preferred reading of the Kollouthos dossier.

41 See Ruffini (2011) s.n. Ioulianos 2. Ruffini's Ioulianos 2 is possibly identical to his Ioulianos 1, an endoxotatos apo eparchōn (former prefect) who owned an estate in the vicinity of Aphrodito (P.Cair.Masp. I 67060) and who exercised a certain fiscal authority in the Antaiopolite nome (P.Cair.Masp. I 67285; P.Lond.V 1674.37-38). Yet the estimate of Constantin Zuckerman (in P.Aphrod.Reg., p. 221-222) that this Ioulianos owned about two-thirds of Aphrodito's lands is likely to overstate the case; for a more cautious approach, see Ruffini (2008) 149, following Bagnall (2008) 188-189.

42 Both documents that refer to Ioulianos as an apo archontōn (P.Lond.V 1660.6 and P.Lond.V 1661.5) do not call him an illoustrios, which begs the question of whether the titles possibly share a comparable reputation. 
late 540 s and early $550 s .{ }^{43}$ So it seems remarkable, at the least, that this man was not a local or even from the Thebaid at all, as is apparent from the draft of an imperial rescript that has come down to us in three different manuscripts. In two of them, Ioulianos is referred to by the surname "the Arsinoite." ${ }^{44}$ This passing remark illustrates a lingering problem: it is only by chance that we are able to identify such aristocratic outsiders at all, since writers did not (need to) refer to them by their origin when using the more distinctive titles and epithets. Are cases like Menas' son Theodoros - referred to as a geouchōn in Antaiopolis in a document from Antinoopolis ${ }^{45}$ the rule or the exception? Could there possibly have been more outsiders among the "local" aristocracy who simply escape our notice and represent further "known unknowns"? ${ }^{46}$ Ioulianos' relocation to the Thebaid may have been due to his position of praeses - if this was not simply an honorary attribution - or because he was granted extensive landed estates there as some sort of imperial reward for earlier service that then rendered him eligible or obligated to hold the pagarchy there. ${ }^{47}$ In the case of Ioulianos, this may be speculation, but we will see below that a probable precedent exists.

\section{A literary precedent?}

A pagarch also appears in the Life of Aaron, a late antique Coptic hagiographical work examined in depth by Jitse Dijkstra in his 2008 monograph. ${ }^{48}$ In one passage, Aaron tells the story of Makedonios, the future first bishop of Philae, who explains to Aaron how he originally came to the region of the First Cataract: "For he said to me: 'When I was still a notable, and started to become rich, I went south, because I was

43 PSI IV 283, with Lemaire (2010), attests to Ioulianos' estates and seems to imply (the papyrus is damaged here) that he changed residence because of his holding the pagarchy, and in P.Lond.V 1660, Ioulianos - in contrast to the endoxotate Patrikia - has no representative. His conflicts with the villagers of Aphrodito would also appear to attest to his personal involvement.



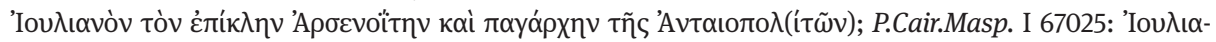

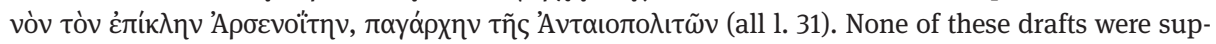
posed to be the final document brought to Constantinople. For a reconstruction of the significance and procedures of petition and rescript, see Zuckerman (2004), especially p. 82-83 and 88-90. 45 P.Lond. V 1714; see above.

46 James G. Keenan, “'Known unknowns': Thoughts on lost (papyrus) evidence”, paper given at the 5th international conference of the research network Imperium and Officium: "Governing ancient empires," Vienna, 5-7 November 2014.

47 Cf. Jairus Banaji's model of a new bureaucratic elite claiming economically powerful local positions based on accomplished imperial service; see Banaji (2007) 101-170, especially p. 128.

48 Dijkstra (2008). See now Dijkstra/Van der Vliet (2020) for a new critical edition with translation and line-by-line commentary. 
pagarch over these cities." 49 It is striking that the text deploys the pagarchy in order to describe Makedonios' motivation for coming to Philae: for the audience of the Life of Aaron, it must have been perfectly plausible that a pagarch could be appointed in a region to which he apparently had little, if any, connection. This is all the more striking since Coptic hagiographic sources only rarely specify public offices, ${ }^{50}$ so the use of the pagarchy must be a significant factor in rendering the narration plausible here.

As we have seen at the beginning of this article, one would not be surprised to find an outsider appointed as pagarch in the Islamic period. It is highly probable, however, that the passage about Makedonios' motives was addressed to a Byzantine audience. ${ }^{51}$ The text of the work has come down to us via a complete tenth-century paper codex, but there is another manuscript only preserved in some small and heavily damaged fragments assigned to the sixth or seventh century on paleographical grounds. ${ }^{52}$ Regarding its overall content, particularly the construction of a Christian identity and the connection to the temple of Isis at Philae, Dijkstra makes a compelling case that the Life of Aaron addresses a sixth-century audience. ${ }^{53}$ The story supposedly takes place in the fourth century and at the beginning of the fifth, yet the image of the pagarch presented here is considerably different from that of the fourth-century officials who held the same title. While the latter were municipal liturgists, each responsible for only fractions of a nome, ${ }^{54}$ the pagarchs from at least the sixth century onward were responsible for the entire rural part of a particular nome. Dijkstra convincingly argues that the compiler of the Life of Aaron drew on an anachronism here in order to explain Makedonios' presence in Philae. ${ }^{55}$

In our context, however, it may still appear conceivable that the pagarchy was attributed to Makedonios only retrospectively after the Islamic conquest, especially

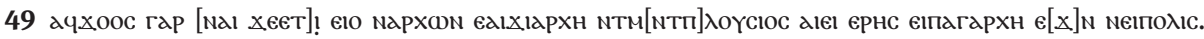
For text and translation, see Dijkstra (2008) 255 and Dijkstra (2007) 193-194. In this literary context, по入ıc certainly has to be taken with a grain of salt, referring to "towns," i.e., larger settlements, rather than "cities" (civitates) in a legal sense.

50 Dijkstra (2008) 261.

51 It is notable that this would make the Life of Aaron one of the earliest Coptic sources to attest a pagarch at all; see the attestations of the Greek loanword in Coptic documentary texts in Förster

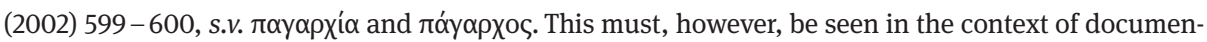
tary habits that only later led to the use of Coptic in administrative and official contexts; see Fournet (2009) 430 - 441, Clackson (2010) 89-104, and Van der Vliet (2013). For another early Coptic testimony of pagarchs, see Johnson (1976) with fragment 2 recto, col. a, 11. $15-24$ of the Coptic Ecclesiastical History (on which in general see Orlandi [2007] 3-25), which is inconceivable in any context other than a Byzantine one; see López (2013) 145 n. 20.

52 The fragments have first been edited in Dijkstra/Van der Vliet (2015); for their paleography, see p. $373-374$.

53 Dijkstra (2008) 329-333.

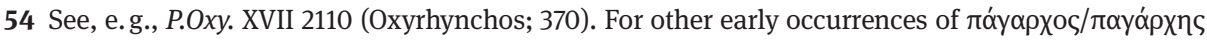
and its cognates, see Stern (2015) 144 n. 107.

55 Dijkstra (2008) 262. 
if such works are to be considered "living literature": a later audience could possibly no longer relate to the text's original reasoning, so the pagarchy would have been added in order to make Makedonios' move plausible again. ${ }^{56}$ Nevertheless, two observations about this passage suggest that it does indeed deal with an essentially Byzantine conception of the pagarchy: first, as Dijkstra notes, the pagarchy in this text is linked to the idea of being rich, which the text conveys through the Greek loanword plousios. This coheres with the liturgical traits of the Byzantine pagarchy, ${ }^{57}$ and since the term is not common in Coptic, ${ }^{58}$ it must be an important feature in rendering Makedonios' link to the pagarchy plausible. And second, to describe Makedonios' position, the Coptic text does not simply attribute the title of pagarch to him but instead draws on the Greek verb pagarchein ("to be pagarch"), which does not occur after the Persian conquest and is thus unlikely to have been inserted at a later date. ${ }^{59}$ So the point stands that a Byzantine audience of the sixth (or early seventh) century seemingly saw nothing odd about a pagarch moving to an obscure remote place in order to exercise the pagarchy there.

\section{Conclusion}

Change is, naturally, ubiquitous. This contribution does not seek to deny that Egypt's administration changed profoundly during the course of the seventh and eighth centuries, nor to imply that pagarchs of Ioulianos' kind "inspired” pagarchs like 'Ațiyya b. Ju'ayd or Nājid b. Muslim. Yet the results draw attention to the manifold faces of the Byzantine pagarchy and its incumbent pagarchs. The individual histories outlined here demonstrate a variety of career patterns: not only were these pagarchs

56 This objection becomes to some degree plausible if the historical Makedonios really held a Roman military function, as hypothesized by Dijkstra (2008) 262. If this was the case, then this would have presumably supplied the original motive for him to come to Philae, but this reasoning would possibly not have been easily understood after the Islamic conquest. On the concept of "living literature," see Dijkstra/Van der Vliet (2015) 385-386.

57 On the liturgical aspects, see Mazza (1995) 196 and 201-202.

58 Dijkstra (2008) 261 with n. 31; the word even lacks an entry in Förster (2002).

59 Dijkstra (2008) 255 n. 8 takes еппагархн to be read either as еппагдpxoc, with the Greek noun act-

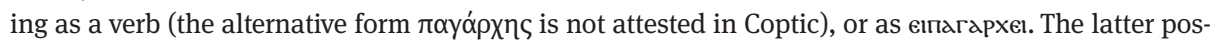
sibility, assuming iotacism, seems the more natural solution. Placed after the more general noun архФм, the verbal expression was possibly chosen for the sake of literary variety. The Greek verb



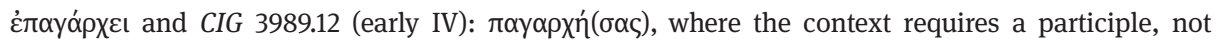

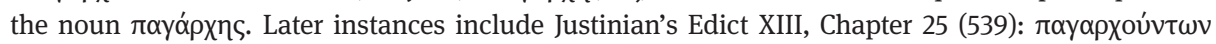
and the aforementioned Oxyrhynchite cases of the passive participle relating to villages, the $\kappa \omega ́ \mu \alpha t$

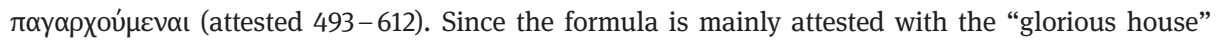
(endoxos oikos) of the Apiones, whose last head in the Oxyrhynchite, Apion III, died in the course of the Persian conquest or shortly afterward, its disappearance may have been due to administrative rearrangements under the Persians. 
firmly integrated into the Byzantine provincial administration, they were also far from being a coherent elite who focused exclusively on their local power base. Some even appear to have been highly mobile career bureaucrats. From this perspective, the Byzantine pagarchy looks less like a concession that a disintegrating state yielded to its aristocracy. Rather, it takes the shape of a deliberate instrument aimed at curbing, channeling, and exploiting aristocratic ambition on various levels - a conception that is also strikingly present in the deliberately anachronistic use of the pagarchy as a literary device in the Coptic Life of Aaron. The claim that the Byzantine pagarchy was fundamentally different from its namesake of the later seventh and eighth centuries further suffers from the accident of preservation ${ }^{60}$ that has left us rather dissimilar types of documents from these periods; these differences render the aspects where the models nonetheless match all the more intriguing.

\section{Bibliography}

Allen (2013): Pauline Allen, "Religious conflict between Antioch and Alexandria c. 565-630 CE", in: Wendy Mayer and Bronwen Neil (eds.), Religious Conflict from Early Christianity to the Rise of Islam (Arbeiten zur Kirchengeschichte 121), Berlin, 187-199.

Bagnall (1993): Roger S. Bagnall, Egypt in Late Antiquity, Princeton 1993.

Bagnall (2008): Roger S. Bagnall, "Village landholding at Aphrodito in comparative perspective", in: Jean-Luc Fournet (ed.), Les archives de Dioscore d'Aphrodité cent ans après leur découverte, Paris, 181-190.

Banaji (2007): Jairus Banaji, Agrarian Change in Late Antiquity. Gold, Labour, and Aristocratic Dominance, rev. ed., Oxford.

Clackson (2010): Sarah J. Clackson, "Coptic or Greek? Bilinguism in the papyri”, in: Arietta Papaconstantinou (ed.), The Multilingual Experience in Egypt, from the Ptolemies to the 'Abbāsids, Burlington, 73-104.

Cromwell (2013): Jennifer Cromwell, "Coptic texts in the archive of Flavius Atias", in: Zeitschrift für Papyrologie und Epigraphik 184, 280-288.

Dikstra (2007): Jitse H. F. Dijkstra, “'Une foule immense de moines.' The Coptic Life of Aaron and the early bishops of Philae," in: Bernhard Palme (ed.), Akten des 23. Internationalen Papyrologenkongresses in Wien, 22.-28. Juli 2001, Wien, 191-197.

Dijkstra (2008): Jitse H. F. Dijkstra, Philae and the End of Ancient Egyptian Religion. A Regional Study of Religious Transformation 298-642 CE (Orientalia Lovaniensia Analecta 173), Leuven.

Dijkstra/Van der Vliet (2015): Jitse H. F. Dijkstra and Jacques van der Vliet, "The earliest manuscript of the Coptic Life of Aaron: British Library, Or. 7558 [89] [93] [150]”, in: Vigiliae Christianae 69, 368-392.

Dijkstra/Van der Vliet (2020): Jitse H. F. Dijkstra and Jacques van der Vliet (eds.), The Coptic Life of Aaron. Critical Edition, Translation and Commentary (Vigiliae Christianae Suppl. 155), Leiden.

60 This is not to say that the preservation of papyri is entirely random, but simply that the picture might be different if we had access to, for instance, the papers that the pagarch Ioulianos or others kept for their own use. 
Förster (2002): Hans Förster, Wörterbuch der griechischen Wörter in den koptischen dokumentarischen Texten (Texte und Untersuchungen zur Geschichte der altchristlichen Literatur 148), Berlin.

Foss (2009): Clive Foss, “Egypt under Mu'āwiya, part I: Flavius Papas and Upper Egypt”, in: Bulletin of the School of Oriental and African Studies 72.1, 1-24.

Fournet (1993): Jean-Luc Fournet, “À propos de SB XIV 11856 ou quand la poésie rencontre le document”, in: Bulletin de l'Institut français d'archéologie orientale 93, 223-235.

Fournet (2000): Jean-Luc Fournet, "Le système des intermédiaires dans les reçus fiscaux byzantins et ses implications chronologiques sur le dossier de Dioscore d'Aphrodité", in: Archiv für Papyrusforschung und verwandte Gebiete 46.2, 233-247.

Fournet (2009): Jean-Luc Fournet, "The multilingual environment of late antique Egypt. Greek, Latin, Coptic, and Persian documentation", in: Roger S. Bagnall (ed.), The Oxford Handbook of Papyrology, Oxford, 418-451.

Gascou (1972): Jean Gascou, "La détention collégiale de l'autorité pagarchique dans l'Égypte byzantine"in: Byzantion 42, 60-72, now as: "La pagarchie collégiale en Égypte byzantine", in: Gascou (2008) 43-50.

Gascou (1985): Jean Gascou, “Les grands domaines, la cité et l'état en Égypte byzantine. Recherches d'historie agraire, fiscale et administrative", in: Travaux et Mémoires 9, 1-90, now in: Gascou (2008) 125-213.

Gascou (2008): Jean Gascou (ed.), Fiscalité et société en Égypte byzantine (Bilans de recherche 4), Paris.

Gelzer (1909): Matthias Gelzer, Studien zur byzantinischen Verwaltung Ägyptens, Leipzig.

Gelzer (1913): Matthias Gelzer, "Altes und Neues aus der byzantinisch-ägyptischen Verwaltungsmisere, vornehmlich im Zeitalter Justinians", in: Archiv für Papyrusforschung und verwandte Gebiete 5, 346-377.

Geraci (1979): Giovanni Geraci, “Per una storia dell'amministrazione fiscale nell'Egitto del VI secolo d. C. Dioskoros e l'autopragia di Aphrodito", in: Actes du XVe Congrès International de Papyrologie à Bruxelles, 29 août-3 septembre 1977, vol. IV, Brussels, 195-205.

Grohmann (1964): Adolf Grohmann, "Der Beamtenstab der arabischen Finanzverwaltung in Ägypten in früharabischer Zeit”, in: Horst Braunert (ed.), Studien zur Papyrologie und antiken Wirtschaftsgeschichte. Festschrift F. Oertel, Bonn, 120-134.

Hardy (1931): Edward R. Hardy, The Large Estates of Byzantine Egypt (Studies in History, Economics and Public Law 354), New York.

Hickey (2012): Todd M. Hickey, Wine, Wealth, and the State in Late Antique Egypt. The House of Apion at Oxyrhynchus (New Texts from Ancient Cultures), Ann Arbor.

Hornickel (1930): Otto Hornickel, Ehren- und Rangprädikate in den Papyrusurkunden. Ein Beitrag zum römischen und byzantinischen Titelwesen, Diss. Gießen.

Johnson (1976): David W. Johnson, "Further fragments of a Coptic History of the Church. Cambridge OR. 1699 R", in: Enchoria 6, 7-17.

Keenan (2001): James G. Keenan, “'Die Binnenwanderung’ in Byzantine Egypt”, in: Greek, Roman, and Byzantine Studies 42, 57-82.

Koch (1903): Paul Koch, Die byzantinischen Beamtentitel von 400 bis 700, Diss. Jena.

Lemaire (2010): Florence Lemaire, "Antimisthosis in the Dioscorus archive”, in: Traianos Gagos and Adam Hyatt (eds.), Proceedings of the 25th International Congress of Papyrology in Ann Arbor, July 29-August 4, 2007, Ann Arbor, 397-408.

Liebeschuetz (1973): J. H. Wolfgang G. Liebeschuetz, "The origin of the office of the pagarch", in: Byzantinische Zeitschrift 66, 38-46.

Liebeschuetz (1974): J. H. Wolfgang G. Liebeschuetz, "The pagarch. City and imperial administration in Byzantine Egypt", in: The Journal of Juristic Papyrology 18, 163-168.

Liebeschuetz (2001): J. H. Wolfgang G. Liebeschuetz, Decline and Fall of the Roman City, Oxford. 
López (2013): Ariel G. López, Shenoute of Atripe and the Uses of Poverty. Rural Patronage, Religious Conflict, and Monasticism in Late Antique Egypt (The Transformation of the Classical Heritage 50), Berkeley.

MacCoull (1988): Leslie S. B. MacCoull, Dioscorus of Aphrodito. His Work and His World (The Transformation of the Classical Heritage 16), Berkeley, Los Angeles, and London.

Maresch (2007): Klaus Maresch, "Vom Gau zur Civitas. Verwaltungsreformen in Ägypten zur Zeit der Ersten Tetrarchie im Spiegel der Papyri”, in: Rudolf Haensch and Johannes Heinrichs (eds.), Herrschen und Verwalten. Der Alltag der römischen Administration in der Hohen Kaiserzeit (Kölner Historische Abhandlungen 46), Köln, 427-437.

Mazza (1995): Roberta Mazza, "Ricerche sul pagarca nell'Egitto tardoantico e bizantino", in: Aegyptus 75, 169-242.

Mazza (2013): Roberta Mazza, “Apiones”, in: Roger S. Bagnall et al. (eds.), The Encyclopedia of Ancient History II, Chichester, 524-526.

Morelli (2014): Federico Morelli, “SB XXIV 16219. Una lettera di Atias in difesa di una donna”, in: Tyche 29, 95-98.

Orlandi (2007): Tito Orlandi, “The Coptic Ecclesiastical History. A survey”, in: James E. Goehring and Janet A. Timbie (eds.), The World of Early Christianity. Language, Literature, and Social Context. Essays in Honor of David W. Johnson (CUA Studies in Early Christianity), Washington, DC, 3-24.

Palme (2016): Bernhard Palme, "Gestellungsbürgschaft an Flavius Strategius Paneuphemos”, in: Eirene 52, 203-211.

Papaconstantinou (2015): Arietta Papaconstantinou, "The rhetoric of power and the voice of reason. Tensions between central and local in the correspondence of Qurra ibn Sharīk", in: Stephan Procházka, Lucian Reinfandt, and Sven Tost (eds.), Official Epistolography and the Language(s) of Power. Proceedings of the First International Conference of the Research Network "Imperium \& Officium: Comparative Studies in Bureaucracy and Officialdom" in Vienna, 10-12 November 2010 (Papyrologica Vindobonensia 8), Vienna, 267-280.

Rémondon (1961): Roger Rémondon, "Soldats de Byzance d'après un papyrus trouvé à Edfou", in: Recherches de Papyrologie 1, 41-93.

Rémondon (1974): Roger Rémondon, “Les contradictions de la societé égyptienne à l'époque byzantine", in: The Journal of Juristic Papyrology 18, 17-32.

Richter (2010): Tonio Sebastian Richter, “Language choice in the Qurra dossier”, in: Arietta Papaconstantinou (ed.), The Multilingual Experience in Egypt, from the Ptolemies to the 'Abbāsids, Burlington, 189-220.

Ruffini (2008): Giovanni R. Ruffini, Social Networks in Byzantine Egypt, New York.

Ruffini (2011): Giovanni R. Ruffini, A Prosopography of Byzantine Aphrodito (American Studies in Papyrology 50), Durham.

Sarris (2006): Peter Sarris, Economy and Society in the Age of Justinian, Cambridge.

Sijpesteijn (2013): Petra M. Sijpesteijn, Shaping a Muslim State. The World of a Mid-Eighth-Century Egyptian Official (Oxford Studies in Byzantium), Oxford.

Stern (2015): Matthias Stern, “Der Pagarch und die Organisation des öffentlichen Sicherheitswesens im byzantinischen Ägypten”, in: Tyche 30, 119-144.

Stern (forthcoming): Matthias Stern, "Disputing public authority in the late antique countryside. P.Cair.Masp. I 67002 revisited" in: Sofie Waebens et al. (eds.), Seeking Justice in and out of Court: Dispute Resolution in Greco-Roman and Late Antique Egypt, Proceedings of an International Conference in Leuven/Brussels, 29 June-1 July 2016, Leuven, forthcoming.

Van der Vliet (2013): Jacques van der Vliet, "Coptic documentary papyri after the Arab conquest", in: The Journal of Juristic Papyrology 43, 187-208.

Van Loon (2017): Guus A. J. C. van Loon, "An orchard lease from the reign of Heraclius", in: Bulletin of the American Society of Papyrologists 54, 127-142. 
Zuckerman (2004): Constantin Zuckerman, “Les deux Dioscore d'Aphroditè ou les limites de la pétition”, in: Denis Feissel and Jean Gascou (eds.), La pétition à Byzance (Monographies du Centre de recherche d'Histoire et Civilisation de Byzance 14), Paris, 75-92. 
